THE TIME THAT REMAINS 

MER I D I A N

Crossing Aesthetics

Werner Hamacher

Editor 
Translated by Patricia Dailey

Stanford

University

Press

Stanford

California

2005 


\section{THE TIME THAT REMAINS}

A Commentary on the Letter to the Romans

Giorgio Agamben 
Stanford University Press

Stanford, California

English translation (C) 2005 by the Board of Trustees of the Leland Stanford Junior University. All rights reserved.

No part of this book may be reproduced or transmitted in any form or by any means, electronic or mechanical, including photocopying and recording, or in any information storage or retrieval system without the prior written permission of Stanford University Press.

The Time That Remains was originally published in Italian under the title Il tempo che resta. Un commento alla Lettera ai Romani (C) 2000 Bollati Boringhieri.

Permission granted by James J. Wilhelm to reprint his translation of Arnaud Daniel's "Lo ferm voler qu'el cor m'intra" from Il Miglior Fabbro. The Cult of the Difficult in Daniel, Dante, and Pound (Orono: National Poetry Foundation, University of Maine at Orono, 1982).

Printed in the United States of America on acid-free, archival-quality paper

Library of Congress Cataloging-in-Publication Data

Agamben, Giorgio, 1942-

[Tempo che resta. English]

The time that remains : a commentary on the letter to the Romans / Giorgio Agamben ; translated by Patricia Dailey.

p. cm. - (Meridian, crossing aesthetics)

Includes index.

ISBN 978-0-8047-4382-2 (cloth : alk. paper)

ISBN 978-0-8047-4383-9 (pbk : alk. paper)

I. Bible. N.T. Paul-Commentaries. I. Title. II.

Series:

Meridian (Stanford, Calif.)

BS2665.53.A33 2005

$227^{\prime} .107-\mathrm{DC} 22$

2004016692

Original Printing 2005 